Vol. 44, N. 4 : pp. 331 - 335, December, 2001

ISSN 1516-8913 Printed in Brazil

\title{
Isolation and Characterisation of a Reserve Protein from the Seeds of Cereus jamacaru (Cactaceae)
}

\author{
Itayguara Ribeiro da Costa ${ }^{1}$; Petrônio Augusto Simão de Souza ${ }^{1}$; Carlos Bloch Jr. ${ }^{2,3}$; \\ Romulo Marino Llamoca-Zárate ${ }^{1}$ and Francisco A. P. Campos ${ }^{1}$ \\ Departmento de Bioquímica e Biologia Molecular, Universidade Federal do Ceará, Fortaleza - CE, Brasil; \\ Universidade de Brasília ", Instituto de Química, Brasília-DF, Brasil; EMBRAPA-Cenargen " , Brasília, DF, Brasil,
}

\begin{abstract}
We describe here the isolation and characterisation of a major reserve protein from the seeds of Cereus jamacaru. (Cactaceae). This protein has a molecular mass of $5319 \mathrm{kDa}$ and was isolated by a combination of gel filtration chromatography and reverse phase HPLC. The amino acid composition of the protein was determined and it was shown to have similarities with the amino acid composition of several proteins from the $2 S$ albumin storage protein family. The usefulness of this protein as a molecular marker in the Cactaceae is also discussed.
\end{abstract}

Key words: Cereus jamacaru; mandacarú; Cactaceae; seed proteins; 2S albumins

\section{INTRODUCTION}

In semi-arid regions, the succulent stems of the "mandacarú" (Cereus jamacaru Mill) are used as feed for cattle (Braga, 1976). The plant itself, with beautiful flowers and fleshy, red, delicious fruits, are almost a symbol of the Brazilian North-East. Despite the potential of the "mandacarú" as a forage crop and as a fruit crop, very few studies have been made towards helping in exploiting these potentials.

One of the main constraints in the wide utilisation of the "mandacarú" as a forage crop is the low level of proteins in its stem and genetic manipulation of this trait is hampered by a lack of understanding of the patterns of protein deposition and mobilisation in stems and seeds. The aim of the present work was to isolate and characterise a reserve protein from the seeds of "mandacarú".

\section{MATERIAL AND METHODS}

Plant material - Seeds of C. jamacaru were obtained from mature fresh fruits collected in May 1997 at a commercial farm in Madalena, Ceará, Brazil.

Protein extraction and purification - Salt soluble proteins were extracted from flour in $0.1 \mathrm{M}$ Tris/ $\mathrm{HCl}, \mathrm{NaCl} 0.5 \mathrm{M}, \mathrm{pH} 8.0$ for 2 hours. After centrifugation $\left(10000 \mathrm{xg}, 20\right.$ minutes, $\left.4^{\circ} \mathrm{C}\right)$, ammonium sulphate was added to the supernatant to a concentration of $90 \%$ and the precipitated proteins were recovered by centrifugation. After dialysis against distilled water at $4^{\circ} \mathrm{C}$ and centrifugation, the albumin and globulin fractions were obtained. The albumins were fractionated on a Sephacryl S-100-HR column $(80$ x $2.6 \mathrm{~cm})$ equilibrated and eluted in $0.05 \mathrm{M}$ ammonium

Author for correspondence 
bicarbonate at a flow rate of $30 \mathrm{ml} / \mathrm{h}$ and $4.3 \mathrm{ml}$ fractions were collected. This column was previously calibrated using the kit MW-GF-70 for molecular mass 6.5 to $66 \mathrm{kDa}$ from Sigma. The tubes containing the $5.3 \mathrm{kDa}$ protein were pooled together, freeze-dried and fractionated by molecular exclusion-HPLC on a Superdex Peptide HR 10/30 column from Pharmacia Biotech, linked to a HPLC system from Waters Corporation. The column was equilibrated and eluted in $0.05 \mathrm{M}$ ammonium bicarbonate, at a flow rate of 0.5 $\mathrm{ml} / \mathrm{min}$. This yielded a single protein peak that was further fractionated by reverse phase-HPLC (RPHPLC) on a 3.9 × $300 \mathrm{~mm}$ m-bondapak C-18 column (Waters) linked to a HPLC system from Waters Corporation. The column was equilibrated in $0.1 \%$ trifluoracetic acid and proteins were eluted in a linear gradient of $0-60 \%$ acetonitrile in $0.1 \%$ trifluoracetic acid, run in 60 minutes. In all of the chromatographic steps the effluents were monitored at $280 \mathrm{~nm}$. Protein concentration was determined by the protein-dye binding method (Bradford, 1976).

Mass spectrometry - The molecular weight of the protein was measured on a Voyager matrix-assisted laser desorption ionisation time of flight mass spectrometry (MALDI-TOF MS) (PerSeptive Biosystems, Framingham, MA, USA). The spectrometer equipped with delayed-extraction system was operated in linear mode. Sample ions were evaporated by irradiation with a $\mathrm{N}_{2}$ laser at a wavelength of $337 \mathrm{~nm}$ and accelerates as $23 \mathrm{kV}$ potential in the ion source with delay of $150 \mathrm{~ns}$. Samples were ionised with 100 to 200 shots of a 3 ns pulse width laser light. The signal was digitised at a rate of $500 \mathrm{MHz}$ and averaged data was presented to a standard Voyager data system for manipulation.

Amino acid analysis - Protein samples were resuspended in $500 \mathrm{ml}$ of constant-boiling $6 \mathrm{~N} \mathrm{HCl}$ containing $0.1 \%$ phenol. Ten percent of each sample was brought up to a final volume of $150 \mathrm{ml}$ of constant-boiling $6 \mathrm{~N} \mathrm{HCl}$ plus $0.1 \%$ phenol. Hydrolysis was carried out in evacuated, sealed, thick-walled borosilicate glass tubes for 24 hours at $120^{\circ} \mathrm{C}$. Cooled samples were opened and samples were dried under vacuum. Samples were stored at $20^{\circ} \mathrm{C}$ until derivatized. Samples were derivatized with PITC (Pierce) according as described (Bidlingmeyer et al. 1984). The protein hydrolysates were redried twice with ethanol:water:triethylamine $(2: 2: 1, \quad \mathrm{v} / \mathrm{v}), \quad$ and derivatized with ethanol: water: triethylamine: PITC (7:2:2:1, v/v). Samples were analysed by reverse-phase HPLC on a Waters system equipped with a Waters 712 WISP and a Waters system interface module linking the HPLC to a Baseline 810 workstation. A Pico-Tag column for hydrolysate amino acid analysis (Waters) maintained at $46{ }^{\circ} \mathrm{C}$ by a Waters temperaturecontrol module was used in accordance with the manufacturer's recommended procedure. Hydrolysate amino acid standards (Sigma) were used for peak identification and subsequent calculations. Lysozyme was also analysed and the results were compared with published values to ensure the accuracy of the technique. Three independent replicates for each sample were analysed. Selected replicates were analysed in duplicate to ensure repeatability.

SDS-PAGE - Gel electrophoresis was performed using the tricine-SDS polyacrylamide gel electrophoresis method for the separation of low molecular mass proteins (Schagger \& Jagow, 1987). As molecular mass markers, the proteins contained in the kit MW-SDS-17S for molecular mass 3.46 to $16.95 \mathrm{kDa}$ from Sigma were used.

$\mathrm{N}$-Terminal analysis - The assessment of the Nterminal amino acid was done by the DABITC/PITC double-coupling method (Chang et al., 1978), following a previously described protocol (Campos and Richardson, 1984).

\section{RESULTS AND DISCUSSION}

The chromatography of the albumin fraction on a Sephacryl S-100-HR column yielded a major broad protein peak, eluting in the molecular mass range of 10 to $4 \mathrm{kDa}$. The protein profile of every third tube from this peak was analysed by PAGESDS and those tubes containing $5.3 \mathrm{kDa}$ protein at high concentration were pooled together, freezedried and applied to a Superdex Peptide column, equilibrated and eluted in $0.05 \mathrm{M}$ ammonium bicarbonate. This yielded a major peak containing $5.3 \mathrm{kDa}$ protein and several other peaks containing small peptides and unidentified compounds (Figure 1A). Analysis by PAGE-SDS of the peak containing the $5.3 \mathrm{kDa}$ protein indicated the 
presence of minor contaminants. Final purification was achieved by RP-HPLC (Figure 1B), which yielded two protein peaks. The peak eluted at an acetonitrile concentration of $31.5 \%$ a contained the $5.3 \mathrm{kDa}$ protein plus several low molecular weight contaminants. The peak eluted at acetonitrile concentration of $33.14 \%$ had one only component of $5.3 \mathrm{kDa}$. The homogeneity of this fraction was ascertained by SDS-PAGE (Figure 2), MALDITOF analysis (Figure 3) and by N-terminal analysis. The molecular weight calculated from the PAGE-SDS experiments was $6.5 \mathrm{kDa}$, while MALDI-TOF analysis indicated the presence of a major isoform of $5319,9 \mathrm{kDa}$ and a minor component of 5178.1 kDa (Figure 3). This discrepancy between the molecular weight values obtained from SDS-PAGE and MALDI-TOF data, probably arises from the anomalous electrophoretic behaviour which is common to be presented by basic, low molecular weight proteins (Judd, 1994). $\mathrm{N}$-terminal analysis yielded only aspartic acid as $\mathrm{N}$-terminal amino acid. The protein whose purification we described above, comprises $18 \%$ of total salt soluble protein.

The results of the amino acid analysis of the purified protein is shown in Table 1 . The protein is devoid of Ser, Thr and Met and has a high percentage of Arg (48\%) and Glx (21\%). The behaviour of the protein in non-denaturing gels and in ion exchange media (data not shown) indicates that this protein is very basic and therefore most of the amino acids identified as Glx are probably Gln. Seed storage proteins are often rich in the amide amino acids glutamine and asparagine, but may also be rich in arginine (Shotwell \& Larkins, 1989). All three of these amino acids have a high nitrogen-to-carbon ratio, making them particularly suited for nitrogen storage (King \& Gifford, 1997). The overall composition of this protein bears strong resemblance to a $2 \mathrm{~S}$ seed storage protein from Opuntia ficus-indica that we have recently characterized (Uchôa et al., 1998). This may indicate that in the seeds of the Cactaceae the major seed reserve proteins may belong to the $2 \mathrm{~S}$ seed storage protein family. We have recently made a survey of the seed protein pattern of several species of cacti and determined the presence in high concentration of a protein component of $5.3 \mathrm{kDa}$ (data not shown).

In the Cactaceae, three subfamilies are recognised: Cactoideae, Opuntioideae and Pereskioideae (Gibson \& Nobel, 1986), whose genera are subject of diverse taxonomic interpretations (Carreras et al., 1997). Although seed protein data have been successfully applied in taxonomical classifications in various families, only now they have been used in the Cactaceae (Carreras et al., 1997). The small size of the $2 \mathrm{~S}$ seed reserve proteins of the Cactaceae make it relatively easy the acquisition of amino acid composition and amino acid sequence data for these proteins. We believe that these data now could be helpful in the identification of cultivars, as well as for solving classificatory problems. Work toward testing this hypothesis is under way in our laboratory.
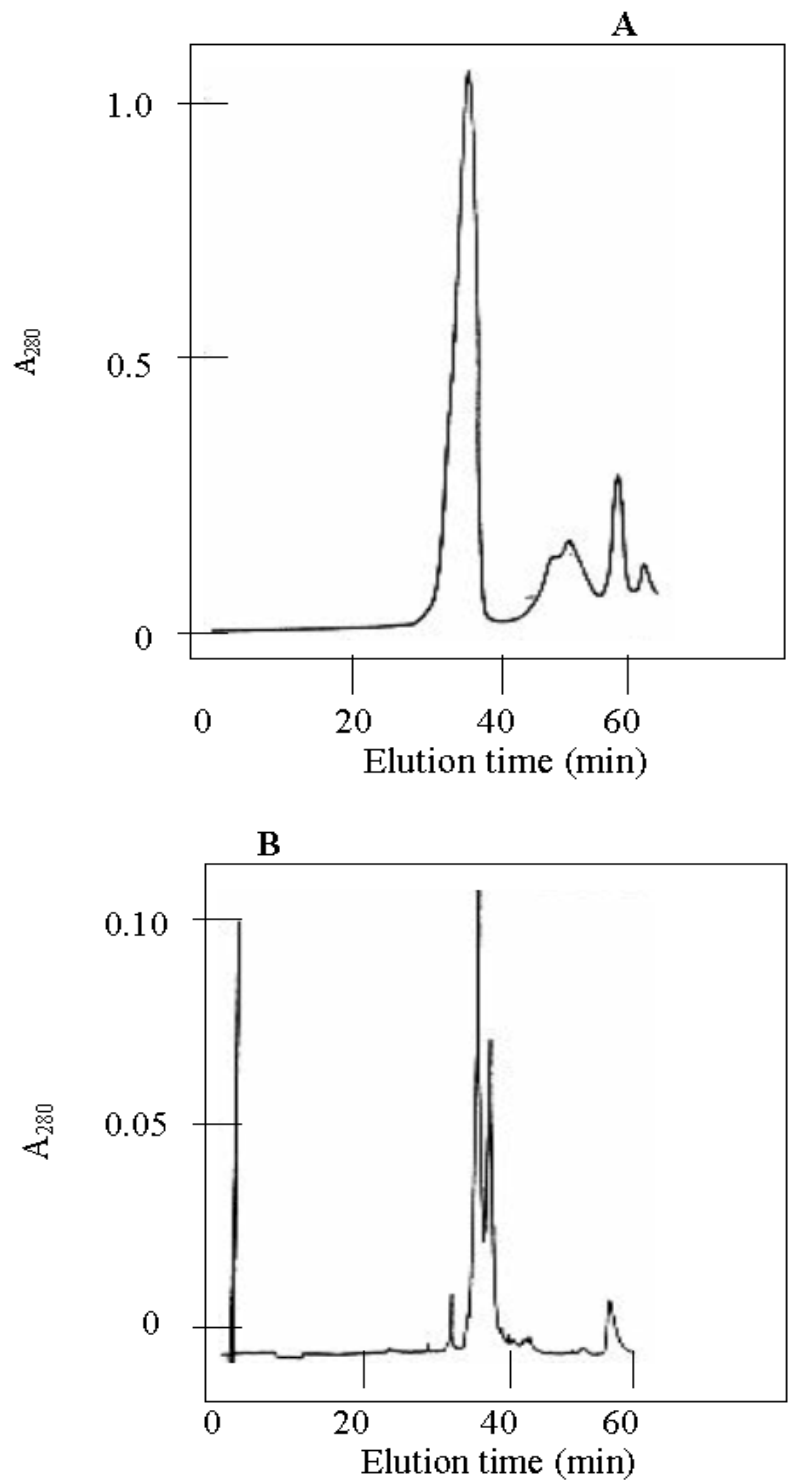

Figure 1 - A, Chromatography of a fraction enriched with the $5.3 \mathrm{kDa}$ protein on a Superdex peptide HR $10 / 30$ column. Proteins (1.0 mg in running buffer) were eluted with $50 \mathrm{mM}$ ammonium bicarbonate at a flow rate of $0.5 \mathrm{ml} / \mathrm{min}$ and samples of $1.0 \mathrm{ml}$ were collected. 
The fractions indicated by the horizontal bar were pooled and subjected to the next purification step. B, RP-HPLC of the fraction enriched with he $5.3 \mathrm{kDa}$ protein on a $\mu$-Bondapak C-18 column. Proteins (200 $\mathrm{mg}$ ) were eluted with a linear gradient of $0-60 \%$ acetonitrile in $0.1 \%$ trifluoracetic acid run for $60 \mathrm{~min}$.

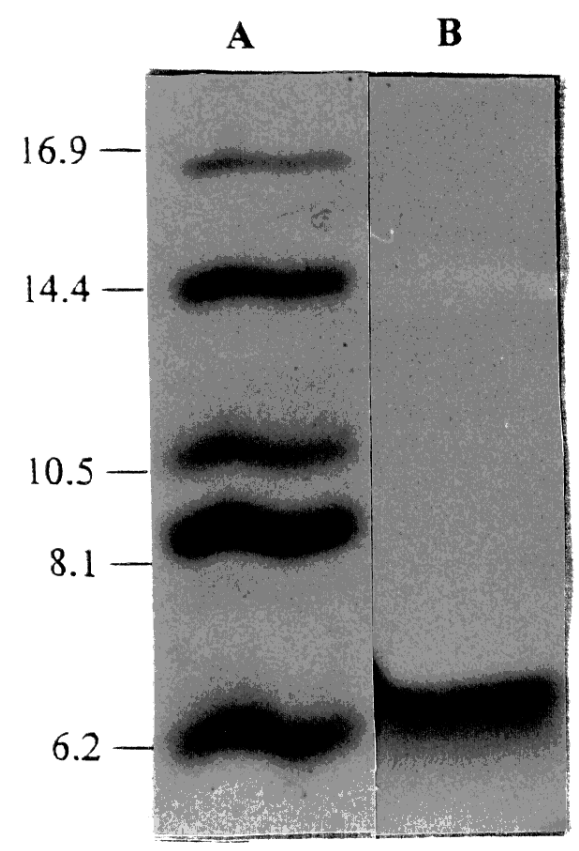

Figure 2 - Assessment by SDS-PAGE of the homogeneity of the $5.3 \mathrm{kDa}$ protein purified from the seeds of $C$. jamacaru. Purified protein $(4 \mu \mathrm{g})$ was added to lane $\mathrm{B}$ and molecular weight markers proteins were added to lane $\mathrm{A}$.

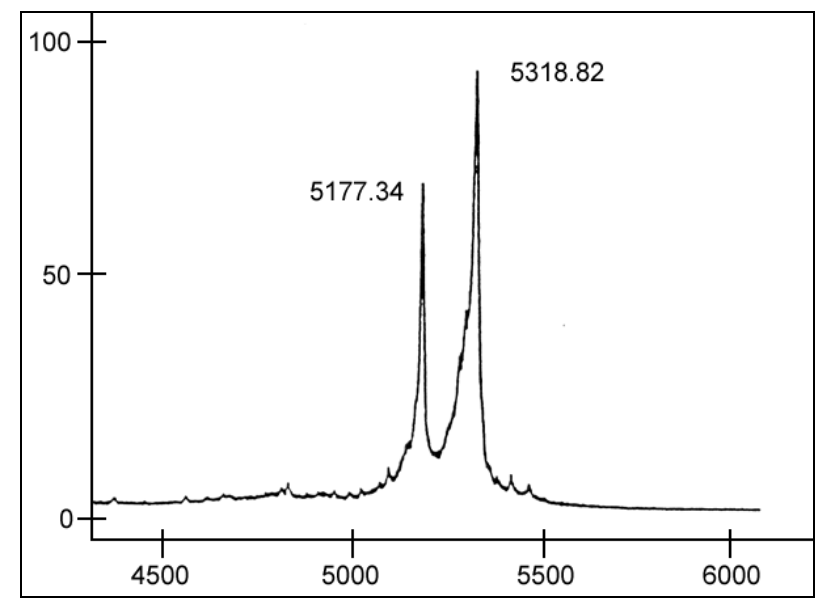

Figure 3 - MALDI-TOF mass spectrum of the reserve protein isolated from the seeds of $C$. jamacaru.
Table 1 - Amino acid composition of the $5.3 \mathrm{kDa}$ protein isolated from the seeds of Cereus jamacaru, as determined by Pico Tag technology. Composition is reported as numbers of residues per mole of protein based on a molecular mass of $5.3 \mathrm{kDa}$. The values for cystein and tryptofan were not determined (nd). Number within parentheses represent the assigned integral values.

\begin{tabular}{cc}
\hline Amino Acid & N. of Residues \\
\hline Asx & $1.22 \pm 0.01(1)$ \\
Glx & $21.78 \pm 0.11(22)$ \\
Ser & $0.05 \pm 0.00(0)$ \\
Gly & $3.20 \pm 0.03(3)$ \\
His & $1.76 \pm 0.02(2)$ \\
Arg & $9.78 \pm 0.10(10)$ \\
Thr & $0.01 \pm 0.00(0)$ \\
Ala & $1.11 \pm 0.02(1)$ \\
Pro & $2.14 \pm 0.06(2)$ \\
Tyr & $1.02 \pm 0.04(1)$ \\
Val & $0.91 \pm 0.01(1)$ \\
Met & $0.02 \pm 0.00(0)$ \\
Ile & $1.11 \pm 0.03(1)$ \\
Leu & $2.25 \pm 0.06(2)$ \\
Phe & $2.17 \pm 0.05(2)$ \\
Lys & $0.01 \pm 0.00(0)$ \\
Trp & Nd \\
Cys & Nd \\
\hline
\end{tabular}

\section{ACKNOWLEDGEMENTS}

The financial support received from $\mathrm{CNPq}$ (Brazilian National Research Council) is gratefully acknowledged.

\section{RESUMO}

A proteína de reserva mais abundante das sementes de Cereus jamacaru (Cactaceae) foi isolada e caracterizada. Esta proteína tem uma massa molecular de $5319 \mathrm{kDa}$ e foi isolada através de uma combinação de técnicas de filtração em gel e HPLC de fase reversa. A composição de aminoácidos da proteína foi determinada e possui similaridade com a composição de aminoácidos de diversas proteínas de reserva de sementes que pertencem à família das albuminas. A utilidade desta proteína como um marcador molecular para as cactáceas é também discutida. 


\section{REFERENCES}

Bidlingmeyer, B. A.; Cohen, S. A. and Tarvin, T. L. (1984), Rapid analysis of amino acids using precolumn derivatization. J.Chromat., 33, 93-104.

Bradford, M. A. (1976), Rapid and sensitive method for the quantitation of micrograms quantities of proteins utilising the principle of protein-dye binding. Anal. Biochem., 72, 248-254.

Braga, R. (1976), Plantas do Nordeste, especialmente do Ceará. Coleção Mossoroense, Vol. XLII, Escola Superior de Agricultura de Mossoró, Rio Grande do Norte, Brazil.

Campos, F. A. P. and Richardson, M. (1984), The complete amino acid sequence of the a-amylase inhibitor I-2 from seeds of ragi (Indian finger millet, Eleusine coracana Gaertn.). FEBS Lett., 167, 221225.

Carreras, M. E.; Fuentes, E. and Merino, E. F. (1997), Seed protein patterns of nine species of Cactaceae. Biochem. Syst. Ecol., 25, 43-49.

Chang, J. Y.; Brauer, D. and Witmann-Liebold, B. (1978), Micro-sequence analysis of peptides and proteins using 4-NN-dimethylaminoazobenzene 4'isothiacyanate/Phenylisothiocyanate double coupling method. FEBS Lett., 93, 155-161.
Judd, R. C. (1994), Eleltrophoresis of peptides. In: Basis Protein and Peptide Protocols. Humana Press, New Jersey, 39-48.

King, J. E. and Gifford, D. J. (1997), Amino acid utilisation in seeds of loblolly pine during germination and early seedling growth. Plant Physiol., 113, 11251135.

Gibson, A. C. and Nobel, P. S. (1986), The Cactus Primer. Harvard University Press, Cambridge, MA.

Schagger, H. and Jagow, G. (1987), Tricine-sodium dodecyl sulfate-polyacrylamide gel electrophoresis for the separation of proteins in the range of 1 to $100 \mathrm{kDa}$. Anal. Biochem., 166, 368-379.

Shotwell, M. A. and Larkins, B. A. (1989), The biochemistry and molecular biology of seed storage proteins. In : The Biochemistry of Plants, Academic Press, New York, 15, 297-345.

Uchôa, A. E.; Souza, P. A. S.; Zarate, R. M. L.; GomesFilho, E. and Campos, F. A. P. (1998), Isolation and characterization of a reserve protein From the seeds of Opuntia ficus-indica (Cactaceae). Braz. J. Med. Biol.Res., 31, 757-761. 